\title{
Mechanical rejuvenation to dampen seasonal variation in chemical composition of browse
}

\author{
J. PAUL REYNOLDS, TIMOTHY E. FULBRIGHT, AND SAMUEL L. BEASOM
}

\begin{abstract}
Authors are graduate research fellow, professor, and director, Caesar Kleberg Wildlife Research Institute, Texas A\&I University, Kingsville 78363. Reynold's current address is Texas Agricultural Experiment Station, La Copita Research Area, Rt. 1, Box 203, Alice, Tex. 78332.
\end{abstract}

\begin{abstract}
Nutritional quality of range plants eaten by white-tailed deer (Odocoileus virginionus Raf.) in southern Texas is lowest during summer and fall. Nutritional quality of shrub regrowth is typically elevated for several months following top growth removal. We tested a strategy to temper the summer-fall decline in nutritional quality of guajillo (Acacia berlandieri Benth.) and blackbrush acacia ( $A$. rigidula Benth.) by roller chopping separate, adjacent portions of the habitat each year during early July. Parallel strips of brush $40-\mathrm{m}$ wide and about $1.6 \mathrm{~km}$-long were roller chopped during 1986-87 in a pattern of alternating roller-chopped and nontreated strips. Leaves and twig tips of nontreated plants and of regrowth from roller-chopped plants were collected bimonthly and analyzed for crude protein (CP) and in vitro organic matter digestibility (IVOMD). Crude protein of guajillo leaves and stems was higher for regrowth than for nontreated plants for 6 and 8 months, respectively, after roller chopping in 1987, and IVOMD of leaves increased for 2 months. The CP of blackbrush leaves from regrowth was higher than CP of leaves from nontreated plants for 6 months after roller chopping in 1987 but IVOMD temporarily decreased. Roller chopping in early July may temporarily increase CP of guajillo browse during the late summer and early fall nutritional stress period, but it is not a promising method for rejuvenation of blackbrush browse.
\end{abstract}

Key Words: A cacia berlandieri, A cacia rigidula, blackbrush acacia, brush management, guajillo, Odocoileus virginianus

Nutritional value of range plants eaten by white-tailed deer (Odocoileus virginianus $\mathrm{Raf}$.) in southern Texas is generally highest in the spring and lowest in the summer and fall (Varner et al. 1977, Meyer et al. 1984). Deer are primarily browsers during late summer and fall, whereas forbs constitute the bulk of diets in late winter, spring, and early summer (Meyer et al. 1984, Nelle 1984). Barnes et al. (1991) concluded that late summer is the most stressful time for deer in south Texas because of low dry matter digestibility, digestible energy, and digestible protein in browse. Meyer et al. (1984) speculated that the low quality of late summer diets may limit white-tailed deer populations in the Texas Coastal Bend region.

Manipulating deer habitat to stimulate forb production during late summer is generally precluded by unfavorable growing conditions; however, shrubs will resprout following top growth removal during this period (Everitt 1983). Browse rejuvenation (top growth removal of woody plants) temporarily increases crude protein (CP) and availability of certain browse species (Scifres 1980, Vallentine 1980 ) but effects of the treatment on CP and in vitro organic matter

\footnotetext{
Research was funded by the J.F. Welder Heirs, the Houston Livestock Show and Rodeo Association, Texas A\&I University Faculty Sponsored Research, the National Rifle Association, and the Caesar Kleberg Foundation for Wildlife Conservation. The authors thank L. Bariess, M. Barret, and numerous student helpers for assistance.

Manuscript accepted 18 Apr. 1992.
}

digestibility (IVOMD) of shrubs during the late summer-fall nutritional stress period in southern Texas is unknown. Mechanical browse rejuvenation would be a potential method of increasing the availability of nutritious forage if it resulted in production of sprouts with higher quality during the late summer that is characteristically unfavorable for plant growth. We hypothesized that (1) by roller chopping brush in early July, resprouts with greater CP and digestibility than browse of nontreated plants would be available during late summer and early fall and, as a corollary, (2) by roller chopping separate strips of brush each year, browse with high CP and digestibility relative to nontreated plants would be available in a portion of the habitat on a year-around basis.

Our objectives were to (1) determine the effects of roller chopping on temporal trends in CP and in vitro organic matter digestibility (IVOMD) and on height of guajillo (Acacia berlandieri Benth.) and blackbrush acacia (Acacia rigidula Benth.), and (2) test the hypothesis that regrowth of these 2 species following roller chopping in July would be higher in CP and IVOMD than mature growth during the late summer-fall nutritional stress period. Guajillo and blackbrush acacia are important browse species for whitetailed deer and often dominate shrub communities in southern Texas and northern Mexico (Smith and Rechenthin 1964). Either species may occur in almost pure stands. Varner and Blankenship (1987) found that guajillo and blackbrush acacia comprised 14.8 and $14.0 \%$, respectively, of white-tailed deer diets during August in the northern Rio Grande Plains.

\section{Materials and Methods}

The study was conducted on the 4,800-ha Esperanza Ranch in Duval County, Texas. Climate, soils, and vegetation of the study area are described in Fulbright et al. (1991).

Parallel strips of brush $40-\mathrm{m}$ wide and $1.2-1.8-\mathrm{km}$ long were roller chopped annually in a 405-ha study area using a 6.4-m-wide (about $27,300 \mathrm{~kg}$ ) roller chopper pulled by a crawler tractor in a pattern of alternating roller-chopped and nontreated strips during early July 1986 and 1987 . Separate strips were treated each year.

Leaf and stem samples from the outer $5 \mathrm{~cm}$ of current year's guajillo and blackbrush acacia growth were collected bimonthly from September 1986 to July 1988 from 20 randomly selected unbrowsed plants/treatment/series of strips in 5 series of rollerchopped and nontreated strips. Each series, consisting of a nontreated strip and strips roller chopped each year, was a block in statistical analyses. Samples were dried initially at $40^{\circ} \mathrm{C}$ then to a constant weight at $50^{\circ} \mathrm{C}$, separated by hand into leaves and stems, ground in a Wiley mill through a $1-\mathrm{mm}$ mesh screen, stored in sealed plastic bags, and analyzed in duplicate to determine percent organic matter, CP, and IVOMD. Organic matter was determined by ashing duplicate samples in a muffle furnace at $600^{\circ} \mathrm{C}$ for 6 hours and subtracting ash from $100 \%$. Crude protein was determined by the micro-Kjeldahl procedure (AOAC 1987). In vitro 


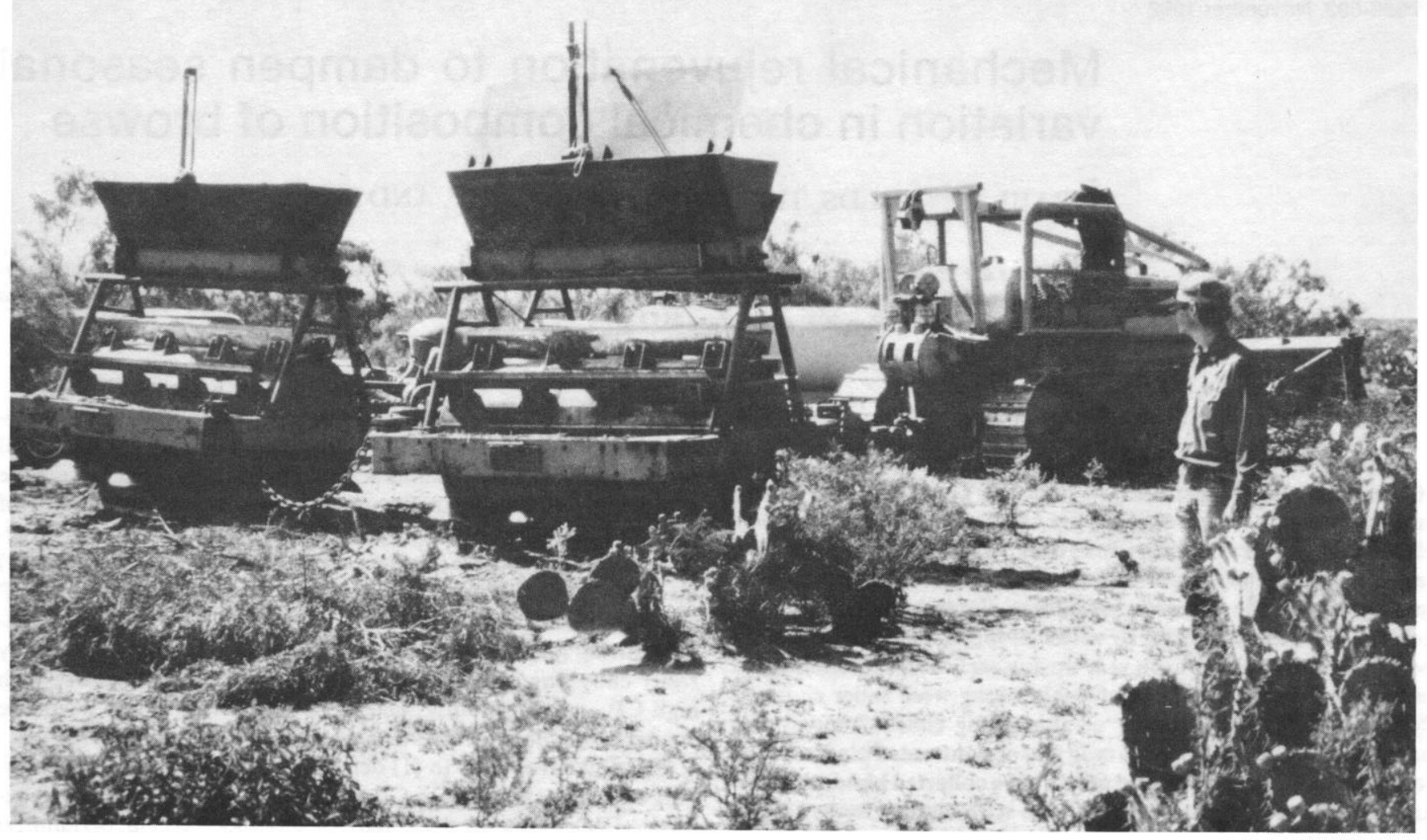

Fig. 1. Two roller choppers pulled in tandem by a crawler tractor to remove top growth of shrubs in southern Texas.

organic matter digestibility was determined following a modified Tilley and Terry (1963) method. Rumen inocula were collected from a Jersey cow (Bos taurus) on a diet of 33\% alfalfa (Medicago sativa $\mathrm{L}$.) and $66 \%$ coastal bermuda grass [Cynodon dactylon (L.) Pers.] hay. Blankenship et al. (1982) reported in vitro dry matter digestibility (IVDMD) of guajillo using deer inocula (34.4\%) to be higher $(P<0.05)$ than digestibility using steer inocula $(28.7 \%)$. In vitro dry matter digestibility of blackbrush acacia was similar $P>0.05$ ) for steer $(20.7 \%)$ and deer $(28.5 \%)$ inocula. Using bovine rumen inocula for in vitro digestion of deer foods is more practical than using deer rumen inocula because rumen fluid is difficult to collect from fistulated deer (Crawford 1984). Campa et al. (1984) suggested that IVDMD values obtained using inoculum from captive and domestic animals on commercial diets can be used to make comparisons of forages and to determine dietary trends, but not to predict digestibility by wild ungulates.

Height of guajillo and blackbrush acacia was determined by measuring 6 randomly selected shrubs of each species in each of 5 strips roller chopped in 1986, 5 roller chopped in 1987, and in 5 nontreated strips during July 1986-88 and October 1986-87.

Guajillo and blackbrush acacia chemical composition and height data were analyzed with a complete-block design with analysis of variance and conservative F tests (Gill 1981). Gill (1981) recommended this design and method of analysis when treatments are not randomized within blocks. Tukey's test was used to separate means $(P \leq 0.05)$. Percentage data were arcsine transformed for analysis; untransformed values are reported. The sampling date $X$ treatment interaction was significant for chemical analyses; therefore, a separate analysis was done for each sampling date.

\section{Results}

Differences in CP between roller-chopped and nontreated guajillo were greatest 2 months after treatment and narrowed thereaf- ter, except during January 1987 (Table 1). Leaves from rollerchopped guajillo were higher in $\mathrm{CP}$ than leaves from nontreated guajillo 2, 6, and 12 months after the 1986 treatment and for 6 months after the 1987 treatment.

Table 1. Temporal trends in crude protein of guajillo leaves and stems of plants from nontreated (Non.) strips and plants roller chopped in July 1986 (RC1986) and 1987 (RC1987), Duval County, Tex., September 1986-July 1988.

\begin{tabular}{|c|c|c|c|c|c|c|}
\hline \multirow{2}{*}{$\begin{array}{l}\text { Sampling } \\
\text { date }\end{array}$} & \multicolumn{3}{|c|}{ Leaves } & \multicolumn{3}{|c|}{ Stems } \\
\hline & Non. & RC1986 & RC1987 & Non. & $\mathrm{RC} 1986$ & RC1987 \\
\hline & & & & & 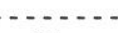 & $-2-3$ \\
\hline Sep. 1986 & $15 b^{1}$ & $20 \mathrm{a}$ & - & $9 b$ & $17 \mathrm{a}$ & - \\
\hline Nov. 1986 & $22 a$ & $22 a$ & - & $11 \mathrm{~b}$ & $16 \mathrm{a}$ & - \\
\hline Jan. 1987 & $15 \mathrm{~b}$ & $23 a$ & - & $10 \mathrm{~b}$ & $18 \mathrm{a}$ & - \\
\hline Mar. 1987 & $28 \mathrm{a}$ & $26 \mathrm{a}$ & - & $19 \mathrm{~b}$ & $22 \mathrm{a}$ & - \\
\hline May 1987 & $21 \mathrm{a}$ & $22 a$ & - & $13 \mathrm{~b}$ & $16 \mathrm{a}$ & - \\
\hline Jul. 1987 & $16 \mathrm{~b}$ & $18 \mathrm{a}$ & - & $10 \mathrm{~b}$ & $13 \mathrm{a}$ & - \\
\hline Sep. 1987 & $13 \mathrm{~b}$ & $14 \mathrm{~b}$ & $22 a$ & $7 b$ & $10 \mathrm{~b}$ & $14 \mathrm{a}$ \\
\hline Nov. 1987 & $14 \mathrm{~b}$ & $16 \mathrm{~b}$ & $20 a$ & $10 c$ & $11 \mathrm{~b}$ & $13 a$ \\
\hline Jan. 1988 & $14 \mathrm{c}$ & $15 \mathrm{~b}$ & $18 \mathrm{a}$ & $11 \mathrm{~b}$ & $12 \mathrm{ab}$ & $13 \mathrm{a}$ \\
\hline Mar. 1988 & $24 a$ & $22 a$ & $16 \mathrm{~b}$ & $10 \mathrm{~b}$ & $10 \mathrm{~b}$ & $12 \mathrm{a}$ \\
\hline May 1988 & $22 a$ & $23 a$ & $23 a$ & $15 \mathrm{a}$ & $15 \mathrm{a}$ & $15 \mathrm{a}$ \\
\hline Jul. 1988 & $17 a$ & $18 \mathrm{a}$ & $19 a$ & $14 \mathrm{a}$ & $13 \mathrm{ab}$ & $12 \mathrm{~b}$ \\
\hline
\end{tabular}

'Leaf or stem means in a row followed by the same letter are similar $(P>0.05)$.

During March 1988, leaves of plants roller chopped in 1987 had lower CP than leaves of nontreated plants or plants roller chopped in 1986. This difference occurred because regrowth from rollerchopped plants retained leaves during January and February. Leaves of nontreated plants and regrowth of plants roller chopped in 1986 senesced in January 1988 and new growth occurred during February and early March 1988. 
Leaves on roller-chopped guajillo were $\geq 18 \% \mathrm{CP}$ on 11 of 12 sampling dates within 1 year posttreatment, whereas those on nontreated plants were $\leq 16 \%$ on 6 of these 12 dates. Additionally, 14-18 months posttreatment, CP of roller-chopped plants had declined to $14-16 \%$. Therefore, the strategy of roller-chopping at 1 -year intervals circumvented the natural pattern of peaks and troughs in leaf $\mathrm{CP}$.

Crude protein of regrowth stems was double that of stems from nontreated plants 2 months after treatment (Table 1). Stems from roller-chopped plants were higher in CP than stems of nontreated plants for 12 months after the 1986 treatment and for 8 months after the 1987 treatment.

Table 2. Temporal trends in in vitro organic matter digestibility of guajillo leaves and stems of plants from nontreated (Non.) strips and plants from strips roller chopped in July 1986 (RC1986) and 1987 (RC1987), Duval County, Tex., September 1986-July 1988.

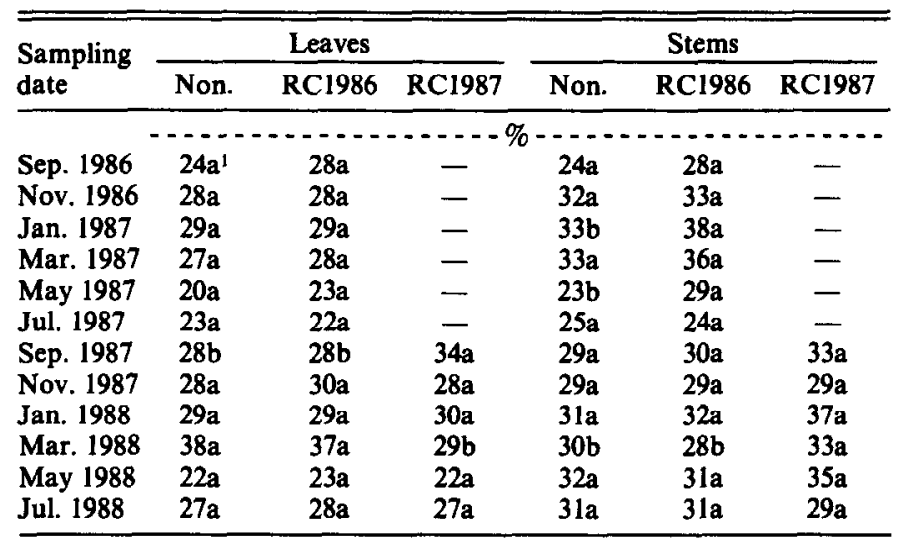

'Leaf or stem means in a row followed by the same letter are similar $(P>0.05)$.

Roller chopping had little effect on IVOMD of guajillo leaves and stems (Table 2). Leaves were higher in IVOMD 2 months after treatment in 1987 but were similar thereafter except in March 1988, when leaves of plants roller chopped in 1987 had lower IVOMD than leaves of nontreated plants or plants roller chopped in 1986. This difference occurred because regrowth from 1987-rollerchopped plants retained leaves during January and February 1988 whereas nontreated plants and plants roller chopped in 1986 were producing new growth during February and early March, as previously discussed for $\mathrm{CP}$.

Table 3. Crude protein content of blackbrush leaves and stems of plants from nontreated (Non.) strips and plants from strips roller chopped in July 1986 (RC1986) and 1987 (RC1987), Duval County, Tex., September 1986-July 1988.

\begin{tabular}{|c|c|c|c|c|c|c|}
\hline \multirow{2}{*}{$\begin{array}{l}\text { Sampling } \\
\text { date }\end{array}$} & \multicolumn{3}{|c|}{ Leaves } & \multicolumn{3}{|c|}{ Stems } \\
\hline & Non. & RC1986 & RC1987 & Non. & RCl986 & RC1987 \\
\hline & \multicolumn{6}{|c|}{ 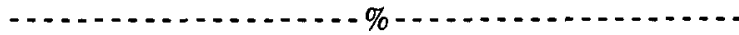 } \\
\hline Sep. 1986 & $12 \mathrm{a}^{1}$ & $14 a$ & - & $7 \mathbf{a}$ & $7 a$ & - \\
\hline Nov. 1986 & $15 a$ & $16 a$ & - & $6 a$ & $6 a$ & - \\
\hline Jan. 1987 & $18 \mathrm{~b}$ & $20 a$ & - & $11 \mathrm{a}$ & $9 \mathrm{~b}$ & - \\
\hline Mar. 1987 & 23a & $21 b$ & - & $14 a$ & $11 \mathrm{~b}$ & - \\
\hline May 1987 & $14 \mathrm{~b}$ & $16 \mathrm{a}$ & - & $7 \mathrm{~b}$ & $8 \mathbf{a}$ & - \\
\hline Jul. 1987 & $15 \mathrm{~b}$ & $17 \mathrm{a}$ & - & $8 \mathbf{a}$ & $9 \mathbf{a}$ & - \\
\hline Sep. 1987 & $12 \mathrm{c}$ & $14 \mathrm{~b}$ & $17 \mathbf{a}$ & 6b & $8 \mathbf{a}$ & 9a \\
\hline Nov. 1987 & $12 \mathrm{c}$ & $14 \mathrm{~b}$ & $15 \mathrm{a}$ & $7 \mathbf{a}$ & $6 \mathbf{b}$ & $6 \mathrm{c}$ \\
\hline Jan. 1988 & $12 \mathrm{~b}$ & $13 \mathbf{a b}$ & $14 a$ & $8 a$ & $6 a$ & $6 a$ \\
\hline Mar. 1988 & $8 \mathfrak{a}$ & $8 a$ & $5 a$ & $6 a$ & $5 a$ & $6 a$ \\
\hline May 1988 & $15 \mathbf{a}$ & $16 a$ & $16 a$ & $7 a$ & $7 a$ & $7 a$ \\
\hline Jul. 1988 & $14 b$ & $14 \mathrm{~b}$ & $15 a$ & $7 b$ & $7 \mathrm{ab}$ & $7 a$ \\
\hline
\end{tabular}

'Leaf or stem means in a row followed by the same letter are similar $(P>0.05)$.
Leaves from blackbrush acacia roller chopped in summer 1987 had higher CP than leaves from nontreated plants $2,4,6$, and 12 months posttreatment (Table 3 ). Leaf CP of roller-chopped plants was similar to that of nontreated plants during the first few months following roller chopping in 1986, although CP was slightly higher 10 and 12 months after treatment. Crude protein content of blackbrush acacia stems from plants roller chopped in summer 1986 was lower than CP of plants from nontreated strips 6,8 , and 16 months posttreatment and higher than $\mathrm{CP}$ of plants from nontreated strips 10 months posttreatment. Stems of plants roller chopped in summer 1987 were higher in CP than stems of nontreated plants 2 months posttreatment and lower 4 months posttreatment.

In vitro organic matter digestibility of leaves from rollerchopped blackbrush acacia was lower than IVOMD of leaves from nontreated plants for 4 months after treatment in 1986 (Table 4).

Table 4. In vitro organic matter digestibility of blackbrush leaves and stems of plants from nontreated (Non.) strips and plants from strips roller chopped in July 1986 (RC1986) and 1987 (RC1987), Duval County, Tex., September 1986-July 1988.

\begin{tabular}{|c|c|c|c|c|c|c|}
\hline \multirow{2}{*}{$\begin{array}{l}\text { Sampling } \\
\text { date }\end{array}$} & \multicolumn{3}{|c|}{ Leaves } & \multicolumn{3}{|c|}{ Stems } \\
\hline & Non. & RC1986 & RC1987 & Non. & RC1986 & RC1987 \\
\hline Sep. 1986 & $26 \mathrm{a}^{\mathrm{I}}$ & $16 \mathrm{~b}$ & - & 21a & $16 \mathrm{~b}$ & - \\
\hline Nov. 1986 & $25 a$ & $21 b$ & - & $21 a$ & $17 a$ & - \\
\hline Jan. 1987 & $28 \mathrm{a}$ & $28 a$ & - & $27 \mathrm{a}$ & $19 b$ & - \\
\hline Mar. 1987 & $24 a$ & $26 a$ & - & $22 a$ & $22 a$ & - \\
\hline May 1987 & $22 a$ & $19 a$ & - & $20 a$ & $18 a$ & - \\
\hline Jul. 1987 & $19 a$ & $20 a$ & - & $20 a$ & $19 a$ & - \\
\hline Sep. 1987 & $25 \mathrm{a}$ & $24 a$ & $22 a$ & $20 a$ & $21 a$ & $22 a$ \\
\hline Nov. 1987 & $25 a$ & $25 \mathrm{ab}$ & $22 b$ & $23 a$ & $19 b$ & $16 c$ \\
\hline Jan. 1988 & $33 a$ & $31 \mathrm{a}$ & $29 a$ & $26 a$ & $23 a$ & $24 a$ \\
\hline Mar. 1988 & $29 a$ & $26 a$ & $18 \mathrm{~b}$ & $25 a$ & $20 \mathrm{~b}$ & $18 \mathrm{~b}$ \\
\hline May 1988 & $25 \mathrm{a}$ & $22 a b$ & $21 b$ & $21 a$ & $17 \mathrm{ab}$ & $16 b$ \\
\hline Jul. 1988 & $22 a$ & $18 \mathrm{ab}$ & $17 \mathrm{~b}$ & $23 a$ & $20 \mathrm{a}$ & $19 a$ \\
\hline
\end{tabular}

${ }^{1}$ Leaf or stem means in a row followed by the same letter are similar $(P>0.05)$.

Stems from roller-chopped plants were lower in IVOMD 2 months after treatment. Following the 1987 treatment, leaves and stems from roller-chopped and nontreated plants had similar or slightly lower IVOMD.

Most regrowth of guajillo and blackbrush acacia occurred during the first 3 months after treatment. Guajillo was $0.83 \pm 0.05-\mathrm{m}(\bar{x}$ \pm SE) tall 3 months after treatment in July 1986 compared to 1.76 $\pm 0.14 \mathrm{~m}$ for nontreated plants. In July 1988 , roller-chopped guajillo plants in July 1986 averaged $0.95 \pm 0.08 \mathrm{~m}$ tall compared to $1.71 \pm 0.21 \mathrm{~m}$ for nontreated plants. Blackbrush acacia plants roller chopped in July 1986 were $0.48 \pm 0.03-\mathrm{m}$ tall 3 months after treatment compared to $1.64 \pm 0.12 \mathrm{~m}$ for nontreated plants. Blackbrush acacia plants roller chopped in 1986 averaged $0.74 \pm 0.04-\mathrm{m}$ tall in July 1988 compared to $1.57 \pm 0.16 \mathrm{~m}$ for nontreated plants.

\section{Discussion}

The low IVOMD of guajillo and blackbrush acacia found in this study agrees with results of Barnes et al. (1991), who found that in vivo digestibility of guajillo in white-tailed deer was $48.1 \%$ in the spring and $35.2 \%$ in the summer. In vivo digestibility of blackbrush acacia averaged 36.3\% (Barnes 1988). Barnes et al. (1991) found that protein digestibility of guajillo was only $45.8 \%$ in spring and $13.7 \%$ in late summer. Thus, although roller chopping increased $\mathrm{CP}$ in our study, digestible protein may be considerably lower.

The lower IVOMD of blackbrush acacia regrowth, as compared to leaves and stems from nontreated plants, possibly resulted in part from increased secondary compounds. Barnes et al. (1988) and Barnes et al. (1991) reported that low dry matter and protein digestibilities in guajillo and blackbrush acacia are positively 
related to high condensed tannin, lignin, and fiber-bound nitrogen levels. Although young leaves of tropical species are more nutritious and less fibrous, they have 2-3 times the concentrations of phenols (Coley 1983). Elevated concentrations of phenols and increased protein binding of phenolic compounds of leaf extracts in poplar (Populus euroamericana Moench.), sugar maple (Acer saccharum Marsh), and red oak (Quercus rubra L.) occurred after $7 \%$ removal of leaves by mechanical defoliation (Schultz and Baldwin 1982, Baldwin and Schultz 1983). Synthesis of these compounds apparently increases in response to damage.

Guajillo and blackbrush acacia browse is available to deer soon after roller chopping, as evidenced by the height of regrowth 3 months after roller chopping and by increases in canopy cover reported by Bozzo et al. (1992a). Bozzo et al. (1992a) reported that canopy cover of guajillo increased from $2.6 \%$ immediately after roller chopping during July to $16.2 \% 3$ months posttreatment. Blackbrush acacia cover increased from $2.8 \%$ immediately after roller chopping to $6.5 \% 3$ months posttreatment.

Bozzo et al. (1992b) reported that white-tailed deer densities were greater in the 405-ha strip-treated area in our study than in a control area of $1.6 \mathrm{~km}$ distant. Deer use increased relative to nontreated sites after $20 \%$ of 3 guajillo-blackbrush acacia-dominated sites ranging from 30- to 125-ha were roller-chopped each year for 2 years. Reasons for increased use were unknown.

\section{Conclusions}

Roller chopping separate strips of brush each year during each July may be a potential strategy to moderate the summer-fall decline in nutritional quality of guajillo. Woody plant stands are essentially replaced in 3 to 4 years after top growth removal (Welch et al. 1985, Scifres 1980). Different strips of guajillo might be roller chopped each year during early July for 3 to 4 years then the strips could be roller chopped again each year in the temporal order that they were originally treated to maintain availability of browse regrowth. Guajillo height and canopy cover increases rapidly following initial treatment; however, further research is needed to determine physiological responses of the shrub to repeated roller chopping to ascertain if the cycle could be repeated indefinitely. The strategy could hypothetically be applied to stands of other shrub species that produce regrowth higher in nutritional quality than mature growth, such as spiny hackberry (Celtis pallida Torr.) (Everitt 1983) and huisache (Acacia smallii Isely) (Rasmussen et al. 1983). Roller chopping does not appear to be a promising method of rejuvenating blackbrush acacia browse during the late summer and early fall because differences in CP between roller-chopped and nontreated plants were small and IVOMD of roller-chopped plants was temporarily lower.

Because of the potential of roller-chopping to ameliorate summer and fall nutritional quality of guajillo, further research on the ability of browse regrowth and mature growth to meet nutritional requirements of deer is warranted. Barnes et al. (1991) pointed out that digestible protein rather than $\mathrm{CP}$ is the nutritionally important factor in meeting animal requirements and that complex relationships exist between nutrient digestibilities and secondary compounds. These relationships for mature browse and regrowth must be understood before definitive conclusions regarding the ability of guajillo and blackbrush acacia browse to meet the nutritional needs of deer can be drawn. A final caveat regarding inferences based on our laboratory analyses on the ability of browse from nontreated or roller-chopped guajillo and blackbrush acacia to provide adequate $\mathrm{CP}$ for herbivores is that animals may select more nutritious plant parts than researchers sampling the plants (Karn and Hofmann 1990).

\section{Literature Cited}

AOAC. 1987. Official method of analyses, 9th ed. Assoc. Off. Agr. Chem., Washington, D.C.

Bald win, I.T., and J.C. Schultz. 1983. Rapid changes in tree leaf chemistry induced by damage: evidence for communication between plants. Science 221:227-279.

Barnes, T.A. 1988. Digestive dynamics of white-tailed deer. Ph.D. Diss., Texas A\&M Univ., College Station.

Barnes, T.A., L.H. Blankenship, and L.W. Varner, 1988. Digestibility of browse utilized by white-tailed deer. In: Abstr. of papers presented at 23rd Annu. Meeting of the Tex. Chap. Wildl. Soc. March, 1988, Del Rio.

Barnes, T.G., L.H. Blankenship, L.W. Varner, and J.F. Gallagher. 1991. Digestibility of guajillo for white-tailed deer. J. Range Manage. 44:606-610.

Blankenship, L.H., L.W. Varner, and G.W. Lynch. 1982. In vitro digestibility of south Texas range plants using inoculum from four ruminant species. J. Range Manage. 35:664-666.

Bozzo, J.A., S.L. Beasom, and T.E. Fulbright. 1992. Vegetation responses to $\mathbf{2}$ brush management practices in south Texas. J. Range Manage. 45:170-175.

Bozzo, J.A., S.L. Beasom, and T.E. Fulbright. 1992. White-tailed deer use of rangeland following browse rejuvenation. J. Range Manage. 45:496499.

Campa, H., III, D.K. Woodyard, and J.B. Haufler. 1984. Reliability of captive deer and cow in vitro digestion values in predicting wild deer digestion levels. J. Range Manage. 37:468-471.

Coley, P.D., 1983. Herbivory and defensive characteristics of tree species in a lowland tropical forest. Ecol. Monogr. 53:209-233.

Crawford, H.S. 1984. White-tailed deer vs. bovine inocula for in vitro digestibilities. J. Wildl. Manage. 48:649-654.

Everitt, J.H. 1983. Effects of plant shredding on nutrient content of four south Texas deer browse species. J. Range Manage. 36:779-781.

Fulbright, T.E., J.P. Reynolds, S.L. Beasom, and S. Demarais. 1991. Mineral content of guajillo regrowth following roller chopping. J. Range Manage. 44:520-522.

Gill, J.L. 1981. Design and analysis of experiments in the animal and medical sciences, vol. 2 Iowa State Univ. Press, Ames.

Karn, J.F., and L. Hofmann. 1990. Relationships between pasture forage components and fecal chemical composition. J. Range Manage. 43:320325.

Meyer, M.W., R.D. Brown, and M.W. Graham. 1984. Protein and energy content of white-tailed deer diets in the Texas Coastal Bend. J. Wildl. Manage. 48:527-534.

Nelle, S. 1984. Key food plants for deer-south Texas, p. 281-291. In:L.D. White and D. Guynn (eds.), Proc. 1984 Int. Rancher's Roundup. Texas Agr. Res. and Ext. Serv., Uvalde.

Rasmussen, G.A., C.J. Scifres, and D.L. Drawe. 1983. Huisache growth, browse quality, and use following burning. J. Range Manage. 36:337-342.

Schultz, J.C., and I.T. Baldwin. 1982. Oak leaf quality declines in response to defoliation by gypsy moth larvae. Science 217:149-153.

Scifres, C.J. 1980. Brush management, principles and practices for Texas and the Southwest. Tex. A\&M Univ. Press, College Station.

Smith, H.N., and C.A. Rechenthin. 1964. Grassland restoration- the Texas brush problem. USDA-SCS, Fort Worth.

Tilley, J.M.A., and R.A. Terry. 1963. A two-stage technique for the in vitro digestion of forage crops. J. Br. Grassl. Soc. 18:104-111.

Varner, L.W., and L.H. Blankenship. 1987. Southern Texas shrubsnutritive value and utilization by herbivores, p. 108-112. In: F.D. Provenza, J.T. Flinders, and E.D. McArthur, (comp.) Symp. on PlantHerbivore Interactions, Snowbird, Utah, August 7-9, 1985. USDA, Forest Serv. Intermount. Res. Sta. Gen. Tech. Rep. INT-222.

Vallentine, J.F. 1980. Range developments and improvements. 2nd ed. Brigham Young Univ. Press, Provo, Ut.

Varner, L.W., L.H. Blankenship, and G.W. Lynch. 1977. Seasonal changes in nutritive value of deer food plants in south Texas. Proc. Annu. Conf. S.E. Assoc. Fish \& Wildl. Agencies 31:399-106.

Welch, T.G., R.P. Smith, and G.A. Rasmussen. 1985. Brush management technologies, p. 15-24. In: Integrated Brush Management Systems for South Texas: Development and Implementation. Tex. A\&M Univ., College Sta. 